\title{
PONSETI METHOD IN BRAZIL: FIRST TEN YEARS OF A CLUBFOOT WEBSITE - USERS PROFILE
}

\section{MÉTODO PONSETI NO BRASIL: 10 ANOS DE UM SITE SOBRE PÉ TORTO - PERFIL DE USUÁRIOS}

\author{
Osias Ferreira Forte ${ }^{1}$ (i), Monica Paschoal Nogueira ${ }^{1}$ (i) \\ 1. Instituto de Assistência Médica ao Servidor Público Estadual (IAMSPE), São Paulo, SP, Brazil.
}

\section{ABSTRACT}

Objective: To analyze the profiles of the individuals who access the website regarding congenital clubfoot (CC) information and the first ten years of Ponseti method implementation in Brazil. Methods: This is a retrospective documentary study, with quantitative database analysis, from 2002 to 2012. Parents or caregivers completed a semi-structured questionnaire regarding the main difficulties encountered, the search for different professionals in the area, and what were the main questions the reader might have when searching on a technical website. Results: In total, $94 \%$ of participants had a family member or acquaintance with $\mathrm{CC}$, most participants were women (74\%), higher education level (40\%), married (75\%), income above one minimum wage (80\%), working in administrative positions $(21 \%$,$) and living in the urban area (99\%). Of the participants, 44 \%$ sought three or more physicians at the beginning of treatment, and an average of $77 \%$ of the participants used health insurance or a private physician. Conclusion: The participants' profile regarding CC is composed of women, married, living in urban areas, predominantly from Southeastern Brazil, higher education level, with income above 1.5 minimum wages, and who were treating their children with a private physician. Level of Evidence II, Retrospective study.

\section{RESUMO}

Objetivo: Analisar o perfil de indivíduos que acessam o site de informações sobre o pé torto congênito (PTC) e o tratamento do Método Ponseti nos primeiros dez anos da implantação do método no Brasil. Métodos: Trata-se de um estudo retrospectivo com análise de bases de dados, de caráter quantitativo, de 2002 a 2012. Aplicou-se um questionário semiestruturado que abordou as dificuldades encontradas, busca por diferentes profissionais e quais eram as principais dúvidas. Resultados: dos respondentes, 94\% tinham algum familiar com PTC, os respondentes foram $74 \%$ do sexo feminino, $40 \%$ com ensino superior, $75 \%$ casados(as), $80 \%$ com renda acima de um salário mínimo, 21\% de cargos administrativos e $99 \%$ residentes em área urbana. Dos respondentes, $44 \%$ procuraram três ou mais médicos no início do tratamento, e, em média, $77 \%$ fizeram o tratamento usando convênio médico ou usando médico particular. Conclusão: O perfil de indivíduos que acessam o site de informações sobre PTC e o tratamento do Método Ponseti é composto de respondentes do sexo feminino, casadas, residentes em área urbana, predominantemente do sudeste do Brasil, com ensino superior, com renda acima de 1,5 salários mínimos, e que estavam tratando seus filhos pela rede de saúde particular. Nível de Evidencia II, Estudo retrospectivo.

Keywords: Clubfoot. Internet. Family. Information.

Descritores: Pé Torto Equinovaro. Internet. Família. Informação.

Citation: Forte OF, Nogueira MP. Ponseti Method in Brazil: first ten years of a clubfoot website - users profile. Acta Ortop Bras. [online]. 2020;28(6):269-274. Available from URL: http://www.scielo.br/aob.

\section{INTRODUCTION}

Internet has evolved exponentially. Just over ten years ago, a computer and telephone network was required to access the internet. Today, you can access it using a phone, tablet, computers, or notebooks. Internet has reached an incredible potential. Through digital technologies, it is possible to know about everything, from everywhere, at any time of day or night. ${ }^{1}$

According to Pandey et al., ${ }^{2}$ the internet has been incorporated in recent years into the millions of lives worldwide, and the individuals can use it to obtain information about health conditions and participate in the disease processes.
In cases of congenital diseases such as clubfoot, the search for information begins soon after the diagnosis. This condition can be identified in the intrauterine period, from the first trimester of pregnancy by ultrasound. It is an orthopedic deformity that involves specialized treatment and affects one in 1,000 live births. ${ }^{3}$

CC treatment underwent significant changes in the early 2000 s. The clubfoot treatment has gone from a long time of serial casts and extensive surgery to a few weeks of casts, minor outpatient surgery, and use of night cast. This new, more efficient, and effective method was proposed by Ponseti. ${ }^{4}$

Twenty years ago, the technique described by Kite $^{5}$ in 1939 was based on serial cast changes, from 6 months to a year,

All authors declare no potential conflict of interest related to this article.

The study was conducted at Instituto de Assistência Médica ao Servidor Público Estadual.

Correspondence: Monica Paschoal Nogueira. Avenida dos Maracatins, 426, Indianápolis, São Paulo, SP, Brazil, 04089000. monipn@uol.com.br 
correcting the adduction first, the varus, and then the equinus. However, most feet could not be corrected after this period, thus requiring extensive surgery, releasing all capsules and medial ligaments of the foot, with fixation in the plantigrade position. Long-term results were still not very satisfactory when considering foot function, showing limited movement, lack of strength, and early arthrosis. ${ }^{3}$

In the 1940s, the Spanish physician Ignacio Ponseti, from the University of lowa, developed a treatment based on the functioning of the foot joints and their movements. The method consisted of specific foot manipulation with weekly serial casts (from five to seven), followed by the complete section of the Achilles tendon under local anesthesia. Continuous use of an abduction brace for three months and after this period only at night until the age of four aims to prevent recurrences. ${ }^{6}$

Our study seeks to understand the profile of the families that search for information on CC, in the first ten years of this transition phase of the clubfoot treatment method, with the beginning of the diffusion of the Ponseti Method in Brazil.

\section{MATERIALS AND METHODS}

This study was approved by the Institutional Review Board and registered on the Plataforma Brazil database under Ethics Evaluation Submission Certificate (CAAE) number: 49627115.8.00005463. All patients have signed an informed consent form.

This is a retrospective documentary study, with quantitative database analysis, from 2002 to 2012.

One hundred twenty-six participants who access the website during the first ten years of Ponseti method implementation in Brazil filled in a questionnaire.

The inclusion criteria were information related to the profile of patients with CC. Incomplete questionnaires were excluded.

\section{Data collection procedure and instrument}

The survey was conducted with the participants who access www.petorto.com.br website and filled in a 38-question semi-structured form.

The questionnaire consisted of socioeconomic information and specific pathology aspects, access to the internet, understanding the level of the information provided in the website, main difficulties encountered, and the main questions the user might have had when browsing a technical website.

The research complied with International Ethical Standards for human research.

\section{RESULTS}

\section{Socioeconomic characterization}

Epidemiological data such as gender, education, marital status, state, city, country, family income, and occupation were evaluated. Most participants were women (74\%), compared to men (26\%). Regarding the educational level, data show that $28 \%$ (35 individuals) were postgraduate, and 40\% (51 individuals) attended an undergraduate course - either concluded or not (Figures 1, 2, 3 and 4).

Data on marital status show that $75 \%$ were married, and $15 \%$ were single. Family income shows that $29 \%$ had an income above 13 minimum wages or more and $14 \%$ had up to 13 minimum wages, 25\% (Figures 1, 2, 3 and 4 and Table 1).

Regarding participants' profession, $21 \%$ were from the administrative area, $20 \%$ from public area, 20\% worked in the health field, $18 \%$ in education, and 8\% were self-employed (Figures 1, 2, 3 and 4).

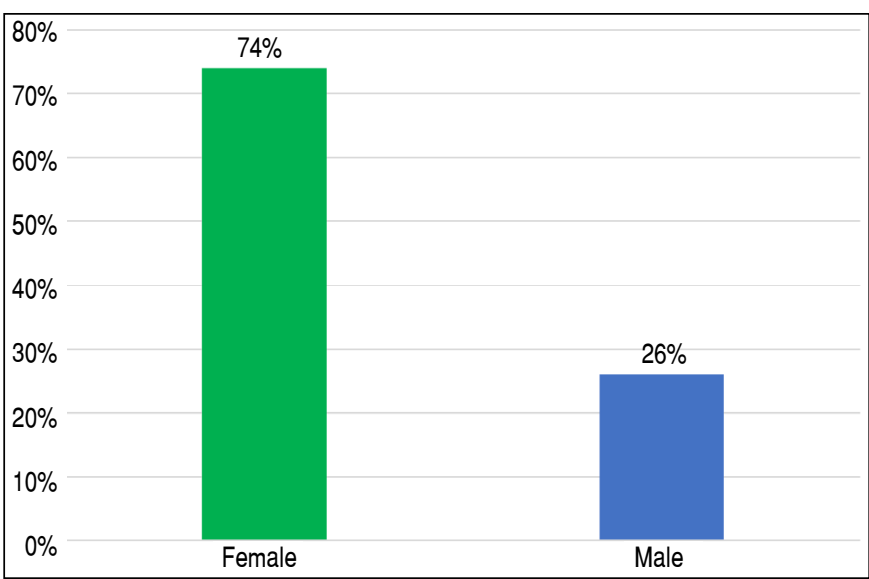

Figure 1. Participants'gender.

Source: Pé Torto?

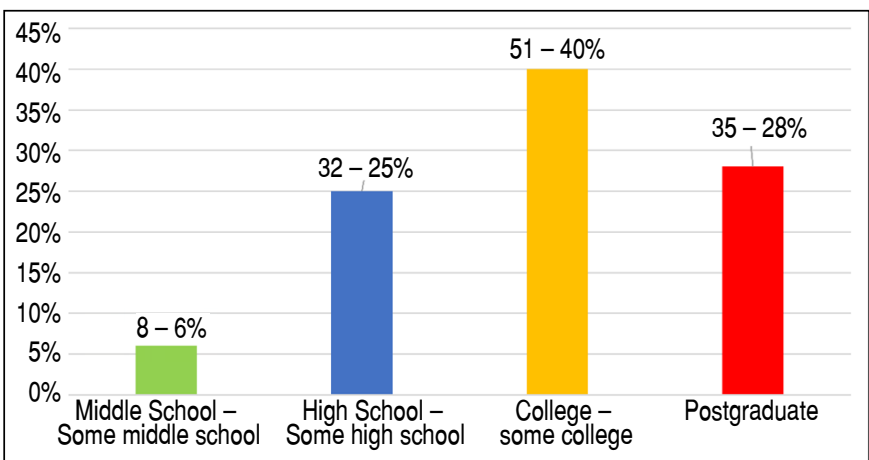

Figure 2. Participants' educational level.

Source: Pé Torto. ${ }^{7}$
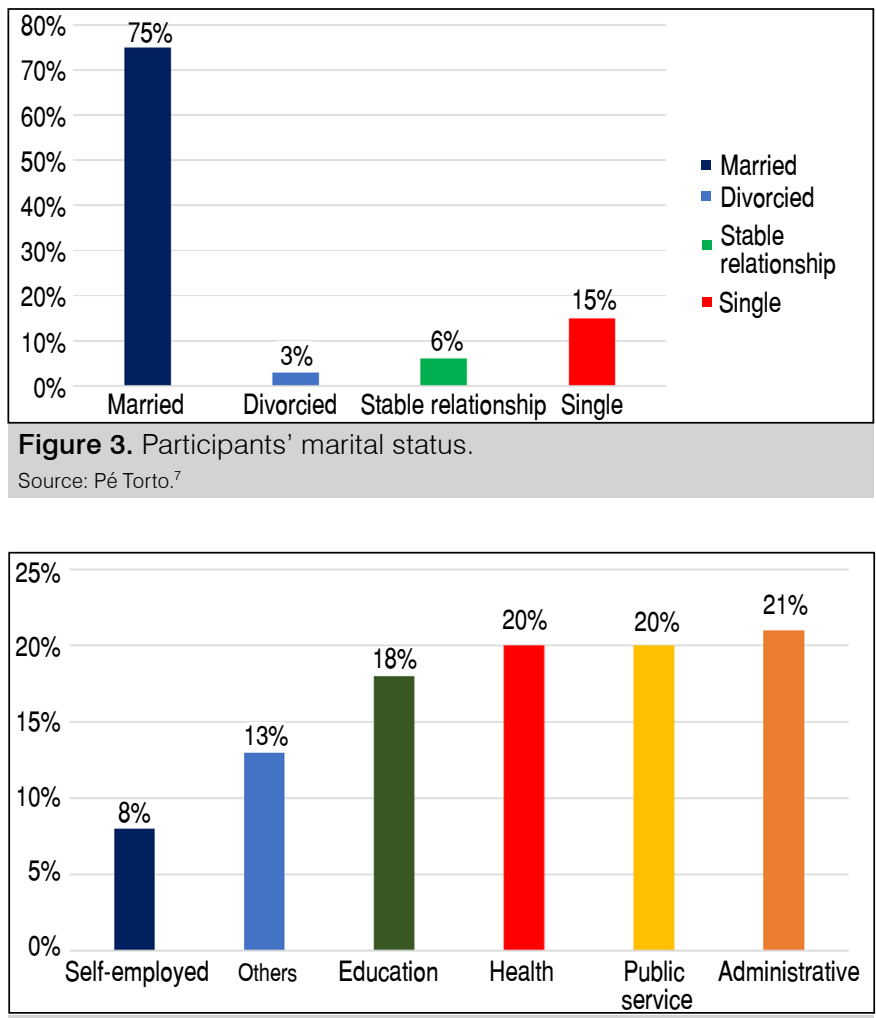

Figure 4. Participants' occupation. Source: Pé Torto? 
Table 1. Participants' family income.

\begin{tabular}{c|c}
\hline Monthly income & $(\mathbf{n = 9 9 ) - \%}$ \\
\hline Up to 3 minimum wage & $4-4 \%$ \\
\hline Up to 4 minimum wage & $13-13 \%$ \\
\hline Up to 5 minimum wage & $14-14 \%$ \\
\hline Up to 8 minimum wage & $25-25 \%$ \\
\hline Up to 13 minimum wage & $14-14 \%$ \\
\hline Over 13 minimum wage & $29-29 \%$
\end{tabular}

Source: Pé Torto

Figure 5 shows the division by state, São Paulo (49 records), Minas Gerais (11 records), Bahia (9 records), Espírito Santo (9 records), Rio de Janeiro (9 records) and Paraná (8 records). The states of Roraima, Pará, Rondônia, Tocantins, Piauí, Rio Grande do Norte and Sergipe had no records on the website.

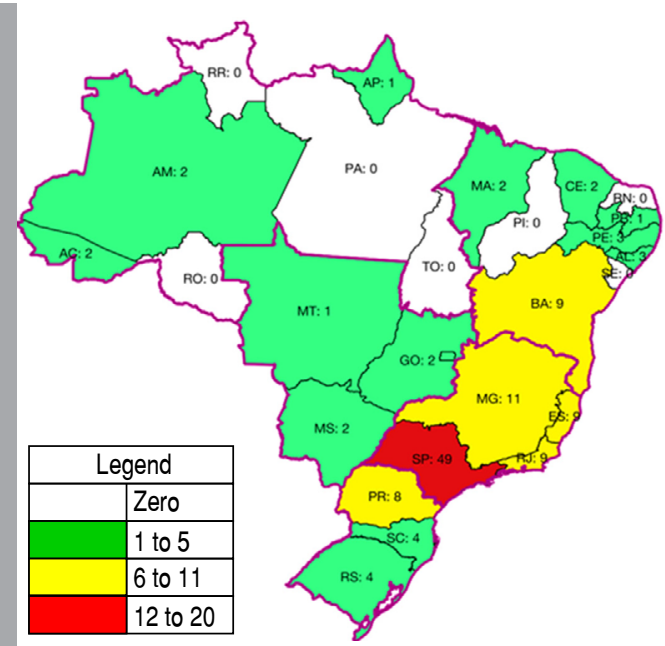

Figure 5. The number of participants who accessed and registered on Pé Torto website, by states and regions of Brazil.

Source: Pé Torto.

The website registration frequency by region was: Southeast 61.90\% ( $n=78)$; Northeast 15.87\% ( $n=20)$; South $12.70 \%(n=16)$; Midwest 5.56\% $(n=7)$ and North 3.97\% $(n=5)$.

Data show that $52 \%$ of professionals were informative and provided information in a humanized manner (Figure 6).

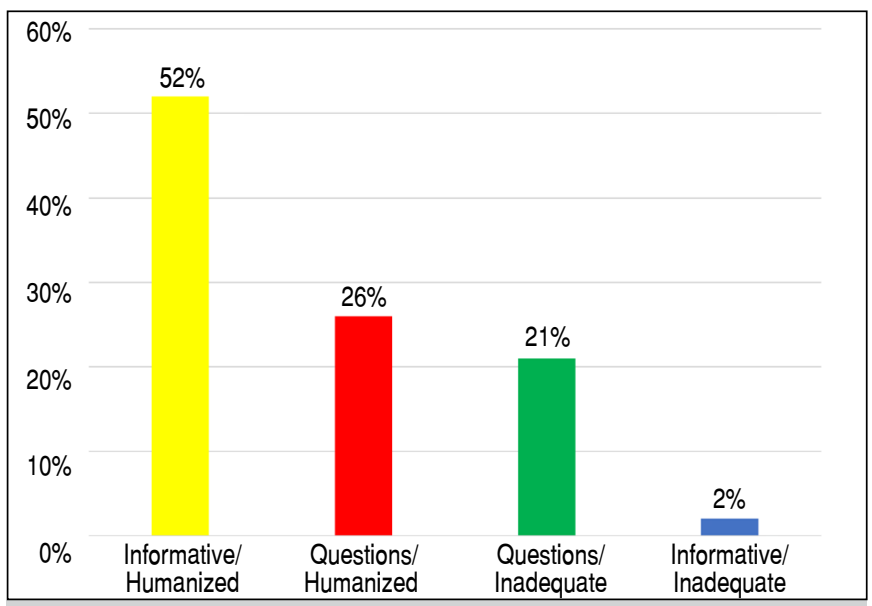

Figure 6. Communication between professionals and participants. Source: Pé Torto. 7
For the clubfoot treatment, an average of $35 \%$ of individuals consulted two physicians; $44 \%$ sought more than three professionals (Figure 7).

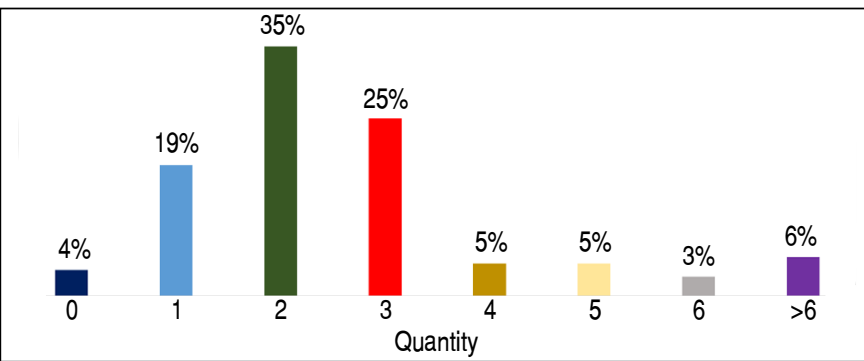

Figure 7. Numbers of consulted physicians regarding congenital clubfoot treatment.

Source: Pé Torto.

Regarding the health system, $83 \%$ of individuals were in private care and $23 \%$ were in public care (Figure 8 ).

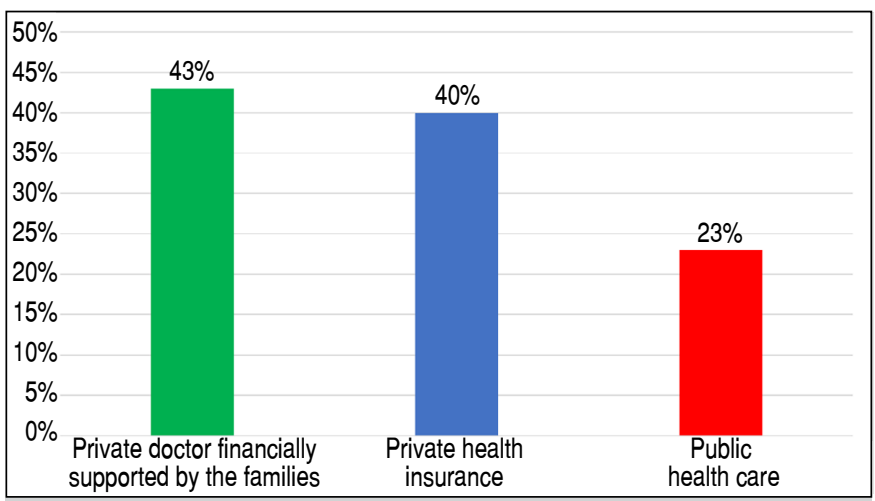

Figure 8. Health system regarding congenital clubfoot treatment. Source: Pé Torto?

Most participants reported undergoing percutaneous Achilles tendon tenotomy treatment (73\%), more than half under general anesthesia (Figure 9).

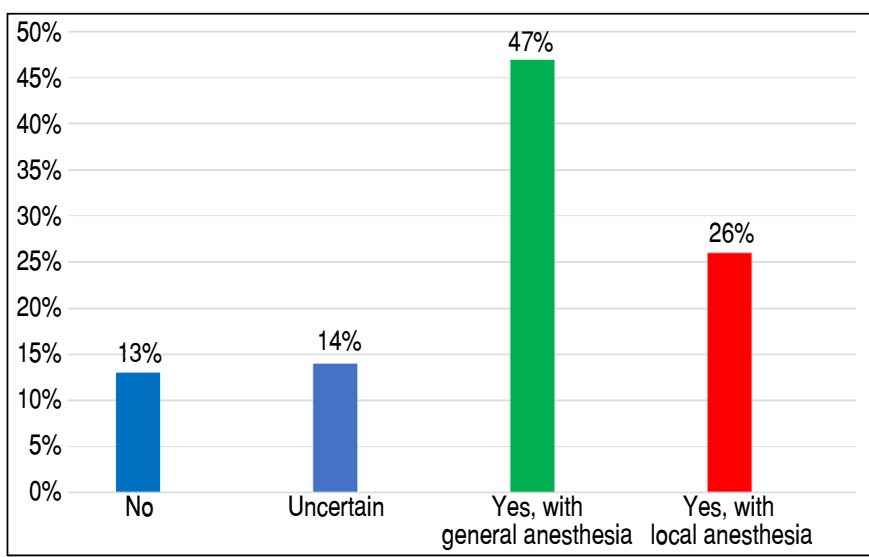

Figure 9. Data on the congenital clubfoot tenotomy procedure. Source: Pé Torto.

Regarding abduction braces during CC treatment, $68 \%$ of the participants reported its use and $20 \%$ declared non-use. Participants reported difficulties in obtaining or acquiring the abduction braces $16 \%$, and $62 \%$ had no difficulty in obtaining it (Figures 10 and 11). 


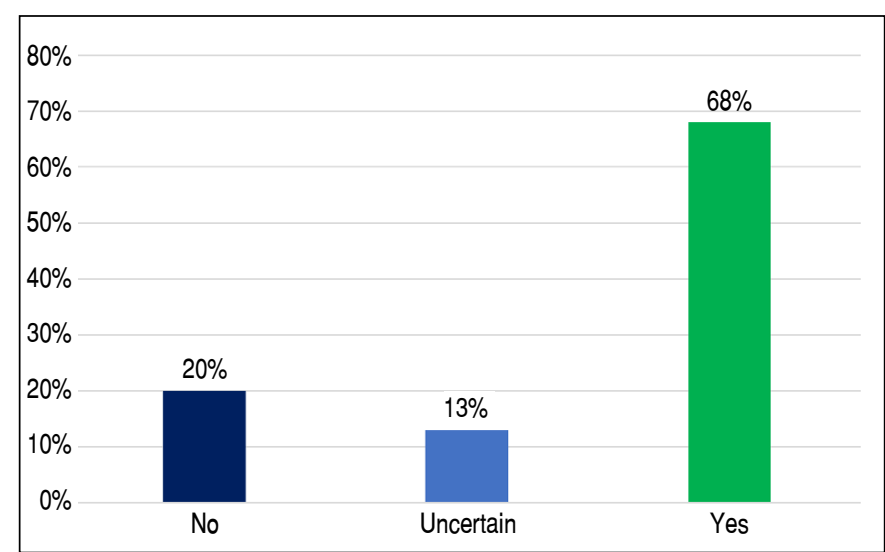

Figure 10. Congenital clubfoot treatment. Source: Pé Torto.?

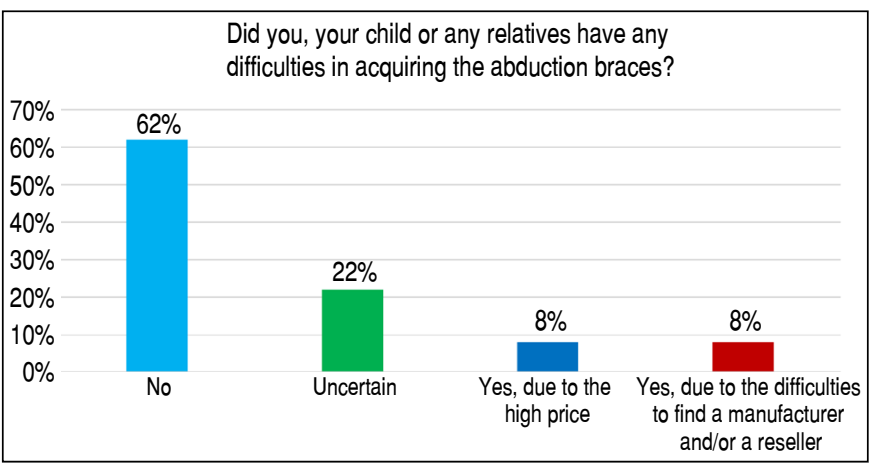

Figure 11. Relationship between the use of braces and difficulties of acquiring it.

Source: Pé Torto. ${ }^{\top}$

Regarding the destination of abduction braces after the treatment conclusion, $31 \%$ donated to the physician, $12 \%$ to other patients with CC, $5 \%$ donated to institutions, $12 \%$ discarded them, and $40 \%$ were uncertain (Figure 12). Regarding the amount paid for the first abduction braces, there was a wilde variation (Figure 13).

Figures 14 and 15 show the continuous use of abduction braces (23 hours a day), 29\% were uncertain, $27 \%$ used during 03 months, $17 \%$ between 04 and 06 months, $12 \%$ between 07 and 12 months, $9 \%$ over 12 months, and $6 \%$ less than 03 months. More than half of the participants (58\%) reported that physicians considered the acquired abduction braces adequate.

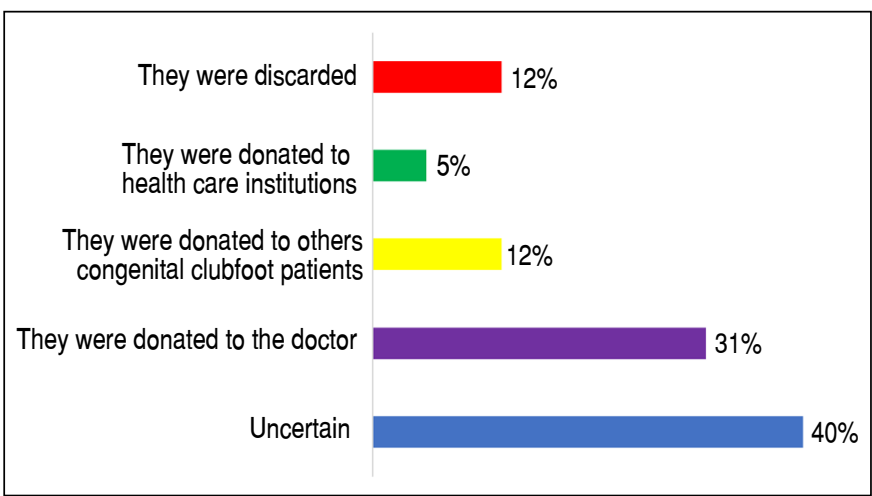

Figure 12. Destination of abduction braces used in the treatment. Source: Pé Torto. ${ }^{7}$

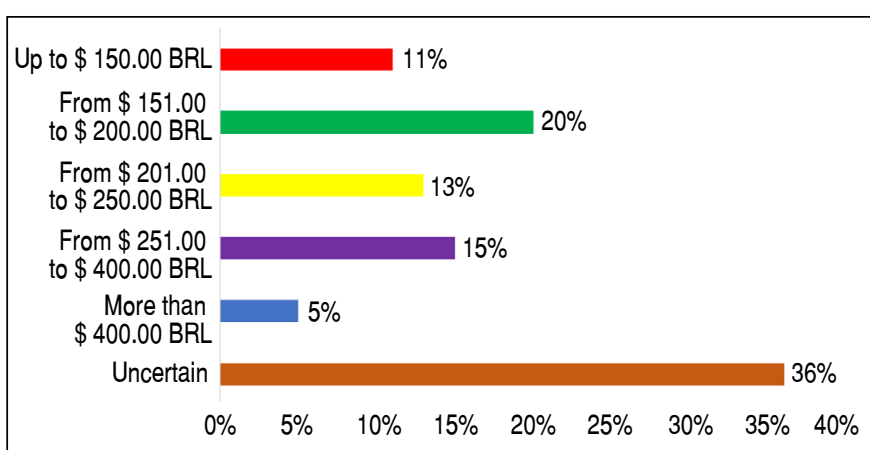

Figure 13. Abduction brace prices in brazilian currency.

Source: Pé Torto?

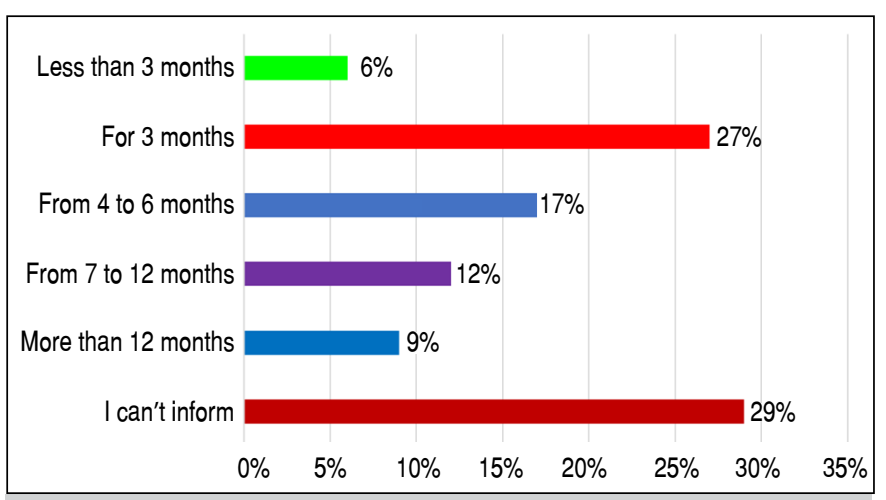

Figure 14. Time of continuous use of foot abduction brace.

Source: Pé Torto. ${ }^{7}$

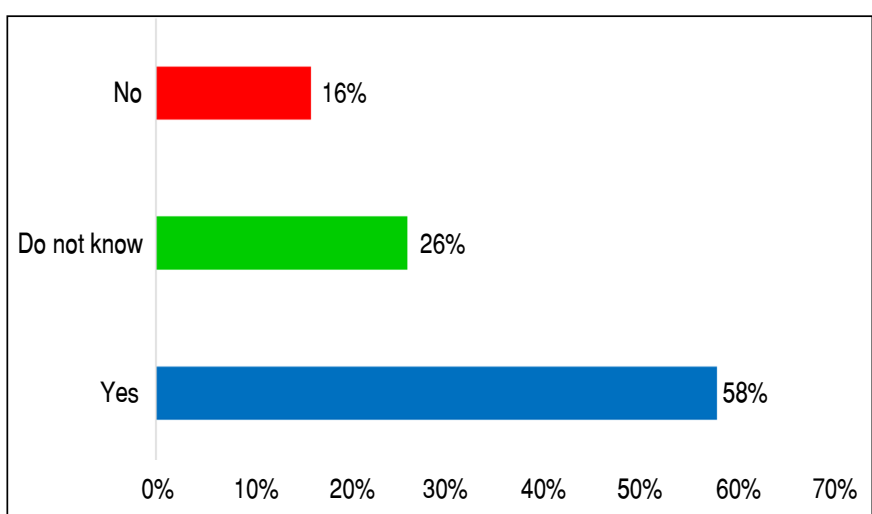

Figure 15. Abduction brace time of use considered adequate by the physician.

Source: Pé Torto. ${ }^{7}$

Figure 16 shows that $29 \%$ used 16 or more casts, $29 \%$ used between 6 and 10,19\% between 1 and 5, and 13\% could not inform.

About $70 \%$ of CC patients used more than six casts; $68 \%$ used abduction braces during treatment, $62 \%$ had no difficulty obtaining/ acquiring it, $41 \%$ donated to the doctor that assisted the patient, $27 \%$ used the braces for 3 months and $58 \%$ considered the first acquired braces adequate.

Ninety-two percent rated the clubfoot website as above 4 on a Likert scale ranging from 1 to 5 .

Among the website users, $63 \%$ asked for a professional's help via the "CONTACT US" link. Of these, $67 \%$ had their questions answered, and $75 \%$ considered that they had received adequate and sufficient information about all stages of CC treatment. 


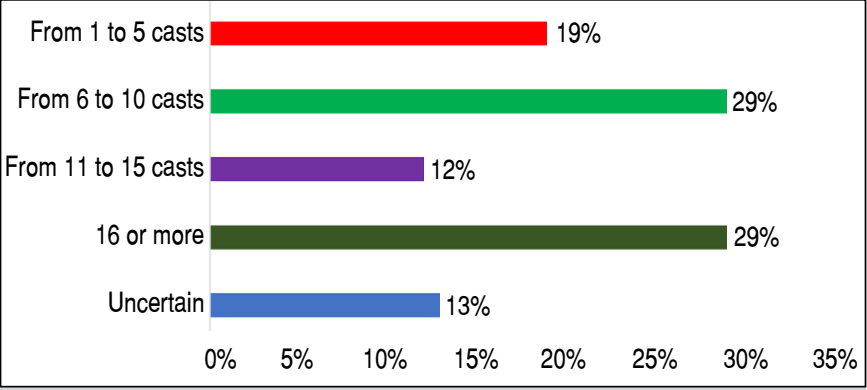

Figure 16. Quantity of casts used during congenital clubfoot treatment. Source: Pé Torto. ${ }^{7}$

\section{DISCUSSION}

From 2002 to 2012, the participants belonged to higher income and educated families, $83 \%$ had the treatment financially supported by the private health system, were mostly from urban areas, with a good socioeconomic level, which justifies the high use of internet to search for more information on CC. Low-income families are not represented in our study, possibly unaware of treatment breakthroughs due to less accessibility to internet.

According to Nogueira, ${ }^{8}$ the families (77\%) search on the internet for more information, since the condition mostly affects one family member, being new in the family nucleus, thus requiring a better understanding. Pregnancy is a period when women are more emotional, fragile, with more free time, and they use this period together with their families to search for information on the internet. Orthopedic consultations for clubfoot treatment (49.7\%) before or after birth by physicians experienced in the Ponseti Method were referenced via the internet. ${ }^{9}$

Brazilian data are comparable to US statistics presented at the Ponseti International Association Meeting, November 2009, Washington - DC. In this study, $74 \%$ of US parents and $51 \%$ parents of other nationalities sought the University of lowa for treating their child using the Ponseti Method after internet searches. ${ }^{10}$

Increased availability of information on professionals and their academic backgrounds is also an essential source of information for patients. The dissemination of knowledge and communication by electronic means still influence clinical practice. Regarding CC treatment, the contribution was vital to the diffusion of the Ponseti Method. ${ }^{11}$ Internet is a fast, convenient, and anonymous source, with abundant information. Due to the continuous advances in technology and increasing accessibility, searching online has become more attractive. Moreover, internet allows access to specific populations, being a useful tool for scientific research groups.

According to Morcuende et al.,11 160 websites provided information on clubfoot and received approximately 30,000 messages (average 1,000 messages/month) posted on the user support area. After visiting internet support groups, 125 parents either changed the treatment to or started treatment for their children with a physician that adopted the Ponseti method.

Skinner et al. ${ }^{12}$ affirm that some issues may affect the quality of access to clubfoot treatment, namely punctuality, literacy, privacy, relevance, and internet access such as by broadband. The authors state that these barriers can hinder the access to health benefits by populations in need.

The survey showed that $91 \%$ of parents interviewed relied on the website to find relevant data, and most adults believe the information found on these websites is reliable, which correlates with the data of our study, validating its reliability. ${ }^{13}$

Patients use health care information to investigate treatment options, to ask new questions, to get a second opinion, which may influence their decision to visit a physician. ${ }^{14}$
Patients consult their physician as a primary source of information. However; internet is increasing as a secondary source, and fewer patients rely on friends, family, journals, radio, or television. ${ }^{15}$ The search for information was positively correlated to social support. One possible explanation is that, when parents search for information about their children's health condition, they are more likely to come across and join an online support community. ${ }^{10}$

Online support communities are an essential source of information for parents. More than $60 \%$ of participants visit an online support community on a regular basis, even daily. ${ }^{16}$

Online communities can be an active channel for parents to seek and provide the information needed to manage clubfoot uncertainties. To improve communication with parents, health institutions should invest in additional resources, e.g. online interactions with caregivers of children with uncommon diseases, such as clubfoot.

Searching and providing information in online communities can provide valuable data for research and interdisciplinary health practice. ${ }^{17}$ Internet offers a means for parents to obtain specific information about diseases in a timely manner. ${ }^{18}$

Percutaneous Achilles tenotomy is part of CC treatment by the Ponseti Method, performed in 90 to $95 \%$ of cases. In the participants of our study, tenotomy was completed in only $73 \%$ of patients. Likewise, abduction braces are also part of the method, and only $68 \%$ of participants confirmed its recommendation/use. In almost half of the cases, participants also reported treatments with more than ten casts. Thus, this information reflects that the Ponseti method has not yet been well established, and its prescription by physicians varied widely. ${ }^{19}$

More than 22 thousand families in Brazil join social networks related to CC treatment by the Ponseti Method, and there is much more consensus regarding the use of braces, the number of casts, and more training of orthopedic surgeons. Several factors contributed to this change, including two major medical training programs organized by the orthopedists' group Ponseti Brazil, part of Ponseti International, for the dissemination and correct use of the Ponseti Method (Nogueira et al. ${ }^{9}$ - Ponseti Brazil Program 2007 and 2008). ${ }^{9}$ One took place in 2007 and 2008, including 556 Brazilian orthopedic surgeons from 21 Brazilian cities in different states that underwent training in a 2-day seminar. A new medical training program, "Eradicating Clubfoot in Brazil" in 2016-2018, a new partnership of the Ponseti Brazil Doctors Group with Rotary, supported by the Association of Parents of Clubfoot, with the training of 50 orthopedists who were already working at the Brazilian Unified Health System (SUS) through the educational model of mentoring. ${ }^{20}$ The treatment of clubfoot by Ponseti Method has become better known, and social networks support this data. ${ }^{21}$

During treatment, parents consulted more than one specialist for a second opinion, and they reported feeling insecure if their medical opinion were clear or objective.

This may reflect the insecurity regarding the change of treatment, of which physicians were still not in consensus on what treatment to adopt. Despite the socioeconomic level, which does not reflect the totality of the parents of clubfoot children in Brazil, participants' families raise doubts, anxieties, and concerns arising from a paradigm shift in the treatment.

\section{CONCLUSION}

The profile of the participants that access the website regarding CC and Ponseti Method is composed of women, married, living in urban areas, predominantly from Southeastern Brazil, having graduated level, with income above 1.5 minimum wages, and that treat their children with a private physician. The gathered information represents the decade (2002-2012) of the change in clubfoot treatment, from cast changes for a long time followed by extensive surgical release to the Ponseti method. 
AUTHORS' CONTRIBUTIONS: Each author contributed individually and significantly to the development of this article. OFF: writing of the article, data analysis and interpretation, article review and approval of the final version of the manuscript; MPN: design and planning of the activities that led to the study, study orientation, critical review, and approval of the final version of the manuscript.

\section{REFERENCES}

1. Aslam N, Bowyer D, Wainwright A, Theologis T, Benson M. Evaluation of Interne use by paediatric orthopaedic outpatients and the quality of information available. J Pediatr Orthop B. 2005;14(2):129-33.

2. Pandey SK, Hart JJ, Tiwary S. Women's health and the internet: under standin gemerging trends and implications. Soc Sci Med. 2003;56(1):179-91.

3. Dobbs MB, Gurnett CA. Update on clubfoot: etiology and treatment. Clin Orthop Relat Res. 2009;467(5):1146-53.

4. Jayawardena A, Boardman A, Cook T, Oprescu F, Morcuende JA. Diffusion of innovation: enhancing the dissemination of the Ponseti method in Latin America through virtual forums. lowa Orthop J. 2011;31:36-42

5. Kite $\mathrm{JH}$. Principles involved in the treatment of congenital club-foot: 1939. J Bone Joint Surg Am. 2003;85(9):1847.

6. Ponseti IV. Congenital clubfoot: fundamentals of treatment. Oxford: Oxford University Press; 1996.

7. Pé Torto [Internet]. São Paulo: Móbile Ortopedia; 2019 [accessed on 2020 Aug 25]. Available from: http://petorto.com.br/.

8. Nogueira MP. Difusão do Método Ponseti para tratamento do pé torto no Brasil: o caminho para a adoção de uma tecnologia [tese]. São Paulo: Faculdade de Saúde Pública; 2011. 227 p.

9. Nogueira MP, Farcetta M. Tratamento de pé torto pela técnica de Ponseti: visão de 91 ortopedistas pediátricos. Proceedings of 43rd Congresso Brasileiro de Ortopedia e Traumatologia; 2011 Nov 13-15; São Paulo. São Paulo: Biblioteca Virtual em Saúde; 2011.

10. Trevillian J. Statistical sampling of parent experiences with clubfoot treatment. Proceedings of Ponseti International Association Meeting; 2009. Washington: Ponseti International Association; 2009.
11. Morcuende JA, Egbert M, Ponseti IV. The effect of the internet in the treatment of congenital idiopathic clubfoot. lowa Orthop J. 2003;23:83-6.

12. Skinner H, Biscope S, Poland B, Goldberg E. How adolescents use technology for health information: implications for health professionals from focus group studies. J Med Internet Res. 2003;5(4):e32.

13. Santos RS, Dias IMV. Refletindo sobre a malformação congênita. Rev Bras Enferm. 2005;58(5):592-6.

14. Lara LCR, Luciano AP, Barros MA, Franco Filho N, Feroldi PC. Avaliação funcional e radiográfica do pé torto congênito tratado cirurgicamente. Rev Bras Ortop. 2007;42(7):217-24.

15. Lara LCR, Montesi Neto DJC, Prado FR, Barreto AP. Tratamento do pé torto congênito idiopático pelo método de Ponseti: 10 anos de experiência Rev Bras Ortop. 2013;48(4):362-7.

16. Yazdy MM, Werler MM. Comparison of web versus interview participants in a case-control study. Ann Epidemiol. 2015;25(10):794-6.

17. Oprescu F, Campo S, Lowe J, Andsager J, Morcuende JA. Online information exchanges for parents of children with a rare health condition: key findings from an online support community. J Med Internet Res. 2013;15(1):e16.

18. Winship B, Grisell M, Yang CB, Chen RX, Bauer AS. The quality of pediatric orthopaedic information on the internet. J Pediatr Orthop. 2014;34(4):474-7

19. Nogueira MP, Fox M, Miller K, Morcuende J. The Ponseti method of treatment for clubfoot in Brazil: barriers to bracing compliance. lowa Orthop J. 2013;33:161-6.

20. Comissão do Boletim Servir. Método Ponseti de tratamento do pé torto congênito. Boletim Servir. 2017;93(4122):1.

21. Maranho DA, Volpon JB. Congenital clubfoot. Acta Ortop Bras. 2011;19(3):163-9. 